\title{
Evaluation the Effect of Low Dose Ionizing Radiation on Radiological Staff
}

\author{
M.H.Khedr \\ Medical Biophysics Division, physics Department, Faculty of Science, Helwan University. Cairo Egypt.
}

\begin{abstract}
The dose and dose-rate is the basic physical factors determining the effects of ionizing radiation on biological systems. It ispredicted that an employers exposed to low dose mayspendfor several months in a radiation field without becoming alarmed. The study aimed to discuss the evaluation of low dose ionizing radiation (IR) effect on some blood components and liver enzymes in radiological staff. Peripheral blood cells count and liver enzyme (SGOT and SGPT) were determined for 11 workers (divided into 2 groups) pre- and post-irradiation. An attempt to explain the blood changes resulting from both irradiation and time is given. There was a strong liner correlation between Peripheral blood cells count and liver enzyme with quarter personal dose but this correlation is not clear for year and Lifetime accumulation dose. The recovery rate of red blood cells (RBC), white blood cells (WBCs), Platelets and liver enzyme preformed to decreasing side effect resulting from year and Lifetime accumulation dose in low dose range but unable to it in quarter accumulation dose.Low dose ionizing radiation lead to short-term effect on blood cells and liver enzyme but biological system as soon as decrease this affects.
\end{abstract}

Keywords: Ionizing-radiation, Low-doses, blood, liver enzyme.

\section{Introduction}

Human are continually exposed to radiation in nature as well as from occupations,medical investigation and consumer products(Hall \&Giaccia, 2008).Biological effects by ionizing radiation depend on dose, dose rate and biochemical processes, effects may be spontaneously, prompt(from day to week) or delayed(Werner, et al 2015), Cell response to ionizing radiation are a variety of ways that differ quantitatively and qualitatively according to the absorbed dose and the cell type(Holl et al., 2000).The prodromal symptoms can be followed by dramatic decrease in peripheral blood cell counts, as hematopoietic cells represent a renewal system consisting of cells with fast division rates that are known to be sensitive to ionizing radiation (Sanzari et al., 2013.

Unfortunately, at very low dose-rates, the total dose that is needed to bring about the tissue effect of hemopoietic failure reaches very high values, so that at low dose-rates hemopoiesis continues to fully function clinically up to very high total doses, as is explained also theoretically (Kutkov, Buglova, \&McKenna, 2011).

Chronic mammals exposure to ionizing radiation low dose-rates affects proliferating cell systems as a function of both dose-rate and the total dose accumulated.The total dose is a higher need for a deterministic effect(Fliedner, et al 2012).they notethe relationship between daily low-dose level exposures and symptoms especially in the rapidly turning over cell so hemopoietic damage depend on dose rate and accumulated dose.Many studies on mice demonstrated that the, lymphocytes, show the most immediate response to ionizing radiation by exhibiting a dramatic drop $24 \mathrm{~h}$ (one day) following irradiation, and then recovery occurs. In contrast, platelets decline more gradually, over a longer time period (Maks et al., 2011;

The aim of the present study is to evaluate low dose ionizing radiation effect on RBCs, WPCs, Platelets and liver enzyme in radiology staff

\section{Material and methods}

Eleven radiation mal worker were used in this study age from 26-37 y this worker divided into two group G1 \& G2, G1 (control Group) three workers, G2 eight worker Length of working period in radiology staff varied from 22 to 96 month (average length 41.75 \pm 22.7 month) the range of Inception Date from 2009 to 2015 Details of occupational and medical history were obtained from a questionnaire form completed by each subject. Subjects who had gross anemia, known history of diabetes mellitus, cardiopulmonary disease, acute or chronic infection, autoimmune disease, malignancy, and current or previous tobacco were excluded from the study.

\footnotetext{
Worker dose

The direct measurement of doses to whole body is only possible for the superficial. DosemetersLuxel+ Ja (Film Badge) located on the worker's chest skin, will allow adequate estimation of the mean dose to whole body.

We've got three main readings from film badge

1. Quarterly accumulated results reflect total dose received within a calendar 3-months timeframe.

2. Year to date accumulation totals dose received from the beginning of the current year to report date.

3. Lifetime accumulation totals all dose received from inception date of dosimeter service to report date.
}

DOI: $10.9790 / 4861-0902010107 \quad$ www.iosrjournals.org $1 \mid$ Page




\section{Blood samples}

Blood samples were collected from the antecubital of radiology staff and persons qualified for the control group (G1) divided into two part

1. Added to sodium strata as an anti-coagulant to evaluate RBCs, WBCs and Platelets

2. Without anti-coagulant used to SGOT and SGPT enzyme from serum

Serum of blood samples was obtained by centrifuging at $5000 \mathrm{rpm}$ for $10 \mathrm{~min}$.

\section{Results}

Table 1 shown the values of working period, Quarterly accumulated Dose mSv, Year to date accumulation Dose $\mathrm{m} \mathrm{Sv}$ and Lifetime accumulationDose $\mathrm{m} \mathrm{Sv}$ for each worker.

\begin{tabular}{|c|c|c|c|c|}
\hline Table 1 & working period & $\begin{array}{c}\text { Quarterly } \\
\text { accumulated Dose } \mathrm{m} \\
\text { Sorker Number }\end{array}$ & $\begin{array}{c}\text { Year to date } \\
\text { accumulation Dose } \mathrm{m} \\
\text { Sv }\end{array}$ & $\begin{array}{c}\text { Lifetime accumulation } \\
\text { Dose } \mathrm{m} \text { Sv }\end{array}$ \\
\hline 1. & 0 & $<0.01$ & $<0.01$ & $<0.01$ \\
\hline 2. & 0 & $<0.01$ & $<0.01$ & $<0.01$ \\
\hline 3. & 0 & $<0.01$ & 0.15 & $<0.01$ \\
\hline 4. & 96 & 0.09 & 0.08 & 0.71 \\
\hline 5. & 40 & 0.05 & 0.04 & 0.35 \\
\hline 6. & 40 & $<0.01$ & 0.05 & 0.1 \\
\hline 7. & 37 & $<0.01$ & 0.25 & 0.26 \\
\hline 8. & 34 & $<0.01$ & 0.09 & 0.29 \\
\hline 9. & 31 & 0.01 & 0.15 & 0.21 \\
\hline 10. & 22 & $<0.01$ & 0.02 & 0.27 \\
\hline
\end{tabular}

Hematological parameters and liver enzymes were determined for each worker. The effect of irradiation dose on RBCs, WBCs and Platelets count and liver enzymes is given in table 2

\begin{tabular}{|c|c|c|c|c|c|}
\hline \multicolumn{6}{|l|}{ Table 2} \\
\hline Worker Number & $\mathrm{RBCs} * 10^{6} \mathrm{~mm}^{3}$ & WBCs $* 10^{3} \mathrm{~mm}^{3}$ & $\begin{array}{l}\text { Platelets } * 10^{3} \\
\mathrm{~mm}^{3}\end{array}$ & SG0T U/L & SGPT U/L \\
\hline 1. & 5.42 & 6.43 & 196 & 18 & 25 \\
\hline 2. & 4.99 & 3.01 & 214 & 20 & 25 \\
\hline 3. & 5.38 & 10.59 & 263 & 16 & 15 \\
\hline 4. & 5.7 & 5.39 & 210 & 39 & 34 \\
\hline 5. & 5.66 & 5.08 & 201 & 19 & 15 \\
\hline 6. & 5.39 & 7.39 & 238 & 23 & 26 \\
\hline 7. & 6.1 & 8.7 & 282 & 35 & 81 \\
\hline 8. & 5.2 & 8.72 & 232 & 15 & 22 \\
\hline 9. & 5.5 & 4.8 & 222 & 17 & 28 \\
\hline 10. & 5.22 & 3.89 & 336 & 28 & 36 \\
\hline 11. & 5,85 & 8.19 & 236 & 35 & 52 \\
\hline
\end{tabular}

Figure 1 histogram illustrate worker number and Length of working period in radiology staff.

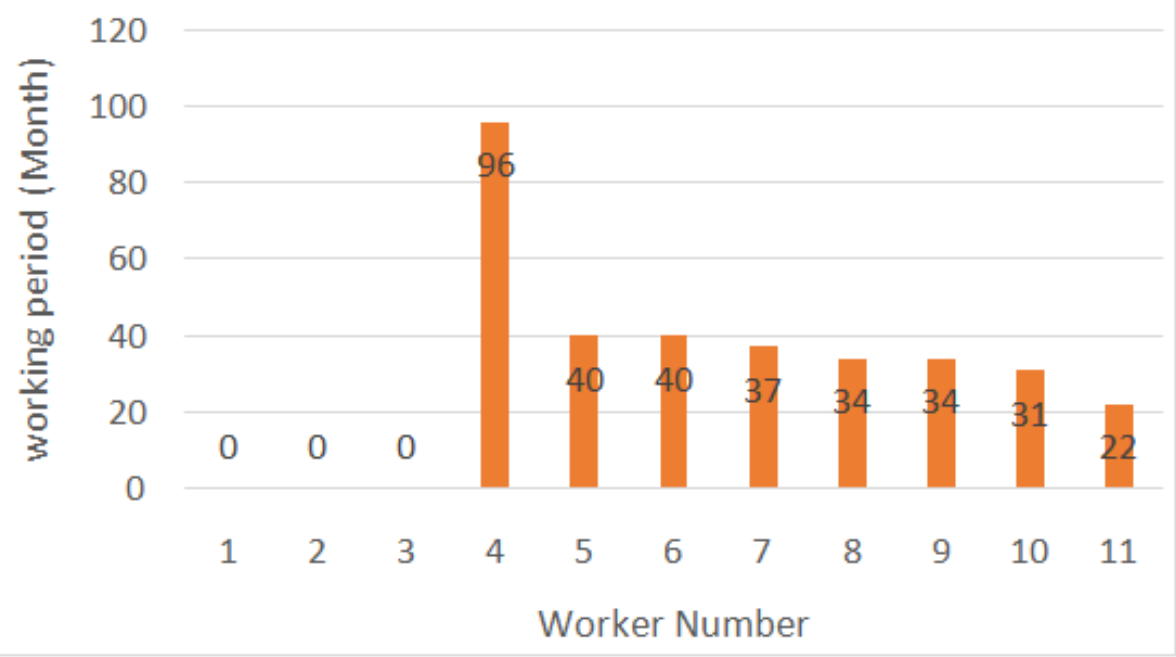

Figure 1 - worker number\& working period 
The correlation between totals dose received from inception date of dosimeter service to report date and Length of working period in radiology staff illustrate in figure 2.

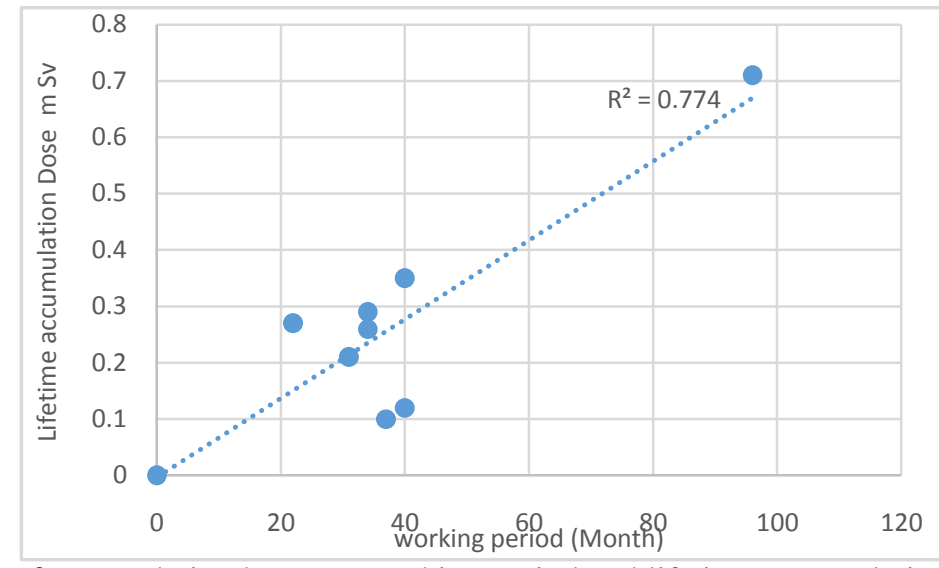

Figure 2 - correlation between working period and lifetime accumulation dose $\mathrm{mSv}$

The correlation between RBCs $* 10^{6} \mathrm{~mm}^{3}$ with Lifetime accumulation Dose $\mathrm{mSv}$, Year to date accumulation Dose $\mathrm{mSv}$ and Quarterly accumulated Dose $\mathrm{mSv}$ illustrate in figure $3 \mathrm{~A}, \mathrm{~B} \& \mathrm{C}$ respectively.

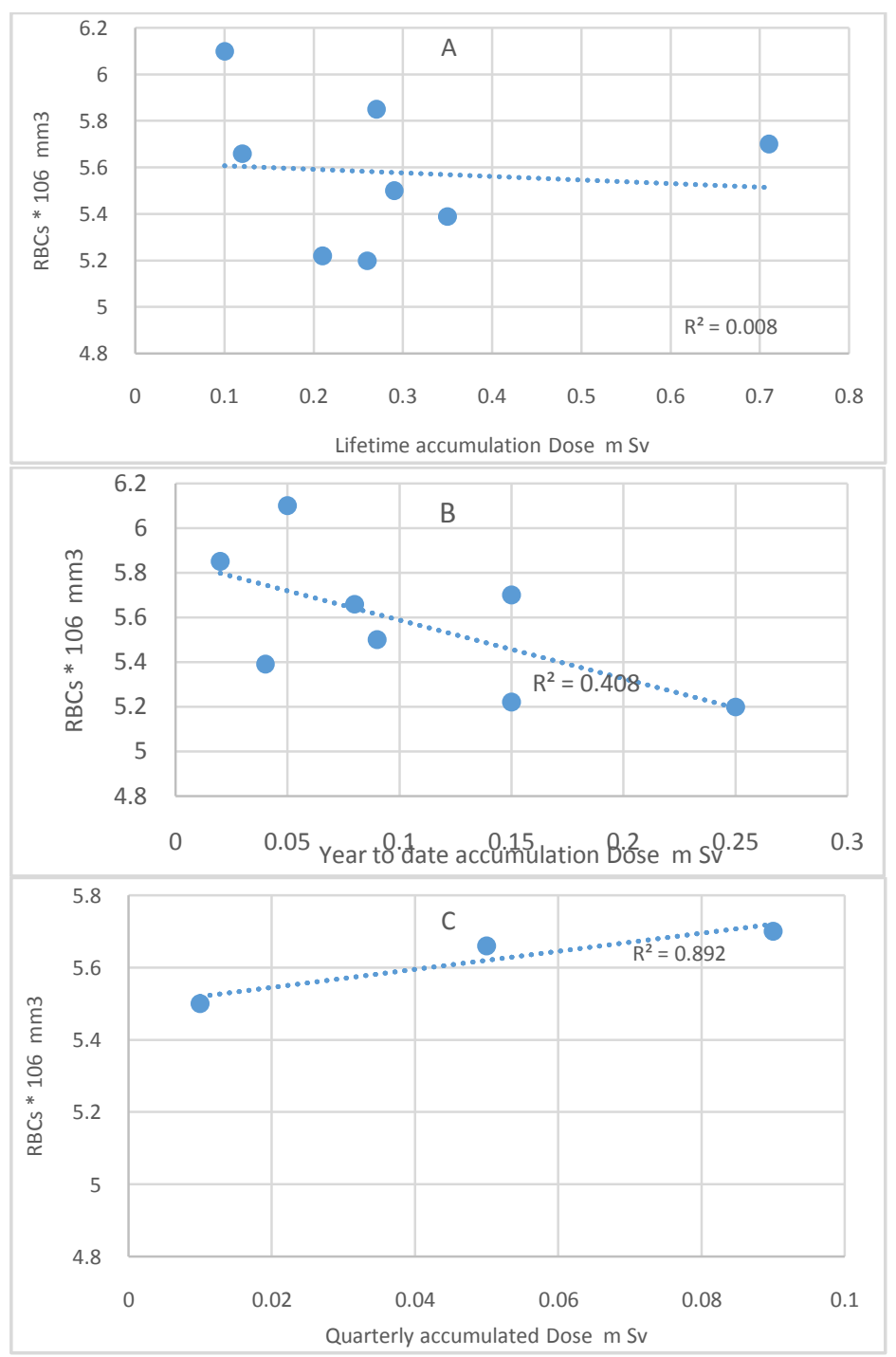

Figure 3 - correlation between RBCs $* 10^{6} \mathrm{~mm}^{3}$ with Lifetime accumulation Dose $\mathrm{mSv}$, Year to date accumulation Dose $\mathrm{mSv}$ and Quarterly accumulated Dose $\mathrm{mSv}$ A, B \& C respectively 
The correlation between WBCs $* 10^{3} \mathrm{~mm}^{3}$ with Lifetime accumulation Dose $\mathrm{mSv}$, Year to date accumulation Dose $\mathrm{mSv}$ and Quarterly accumulated Dose $\mathrm{mSv}$ illustrate in figure $4 \mathrm{~A}, \mathrm{~B} \& \mathrm{C}$ respectively
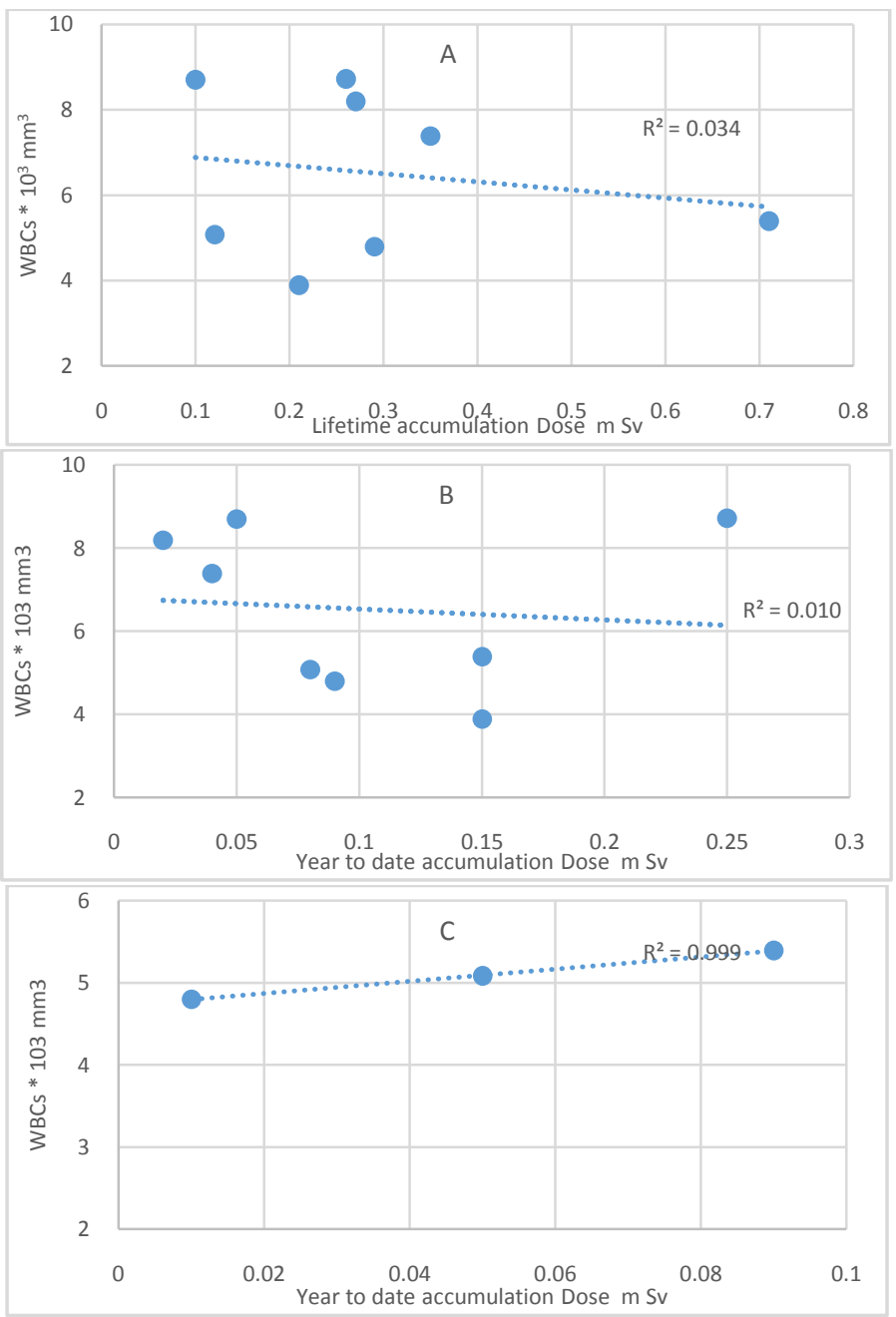

Figure 4 - correlation between WBCs $* 10^{3} \mathrm{~mm}^{3}$ with Lifetime accumulation Dose $\mathrm{mSv}$, Year to date accumulation Dose $\mathrm{mSv}$ and Quarterly accumulated Dose mSv A, B \& C respectively

The correlation between Platelets $* 10^{3} \mathrm{~mm}^{3}$ with Lifetime accumulation Dose $\mathrm{mSv}$, Year to date accumulation Dose $\mathrm{mSv}$ and Quarterly accumulated Dose $\mathrm{mSv}$ illustrate in figure $5 \mathrm{~A}, \mathrm{~B} \& \mathrm{C}$ respectively

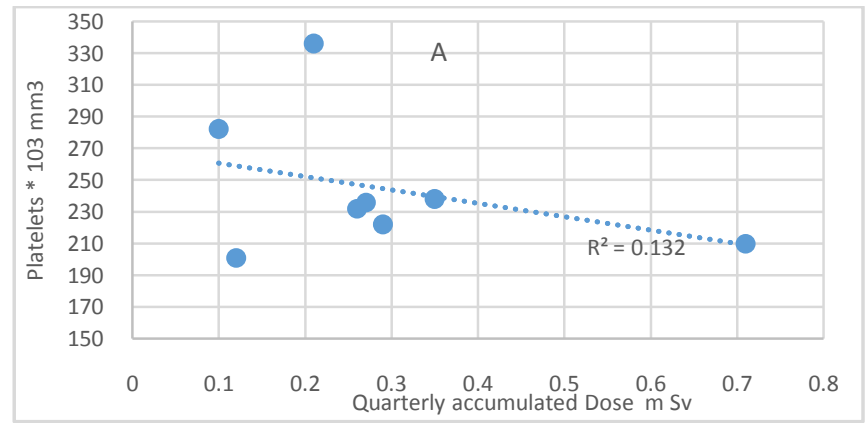




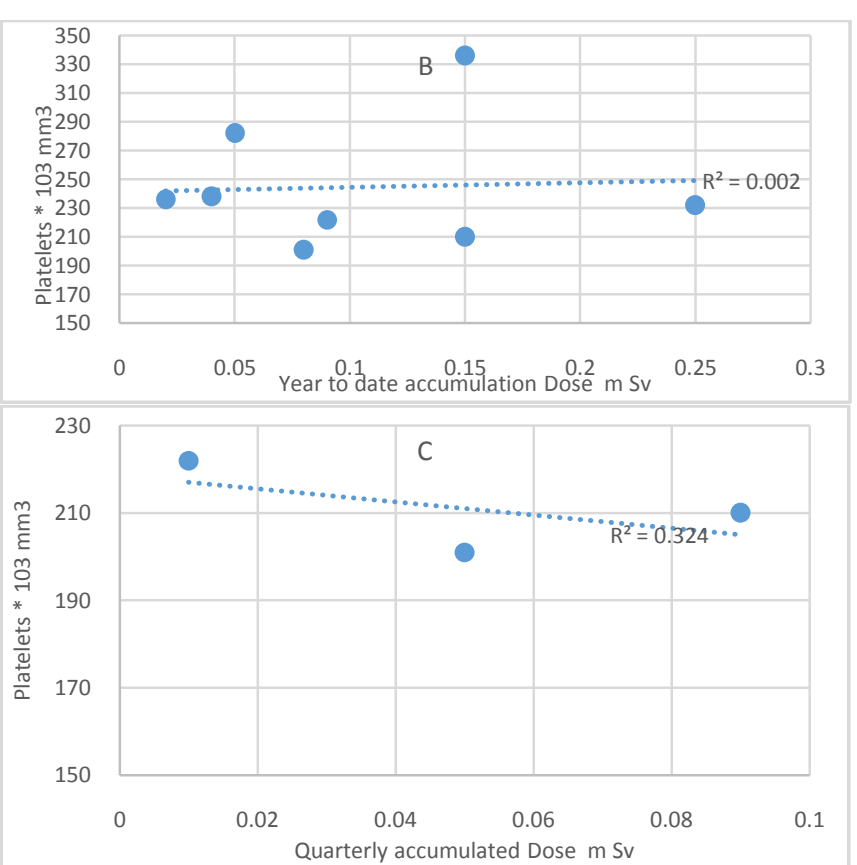

Figure 5 - correlation between Platelets $* 10^{3} \mathrm{~mm}^{3}$ with Lifetime accumulation Dose $\mathrm{mSv}$, Year to date accumulation Dose $\mathrm{mSv}$ and Quarterly accumulated Dose mSv A, B \& C respectively

The correlation between SGOTU/Lwith Lifetime accumulation Dose mSv, Year to date accumulation Dose $\mathrm{mSv}$ and Quarterly accumulated Dose $\mathrm{mSv}$ illustrate in figure $6 \mathrm{~A}, \mathrm{~B} \& \mathrm{C}$ respectively

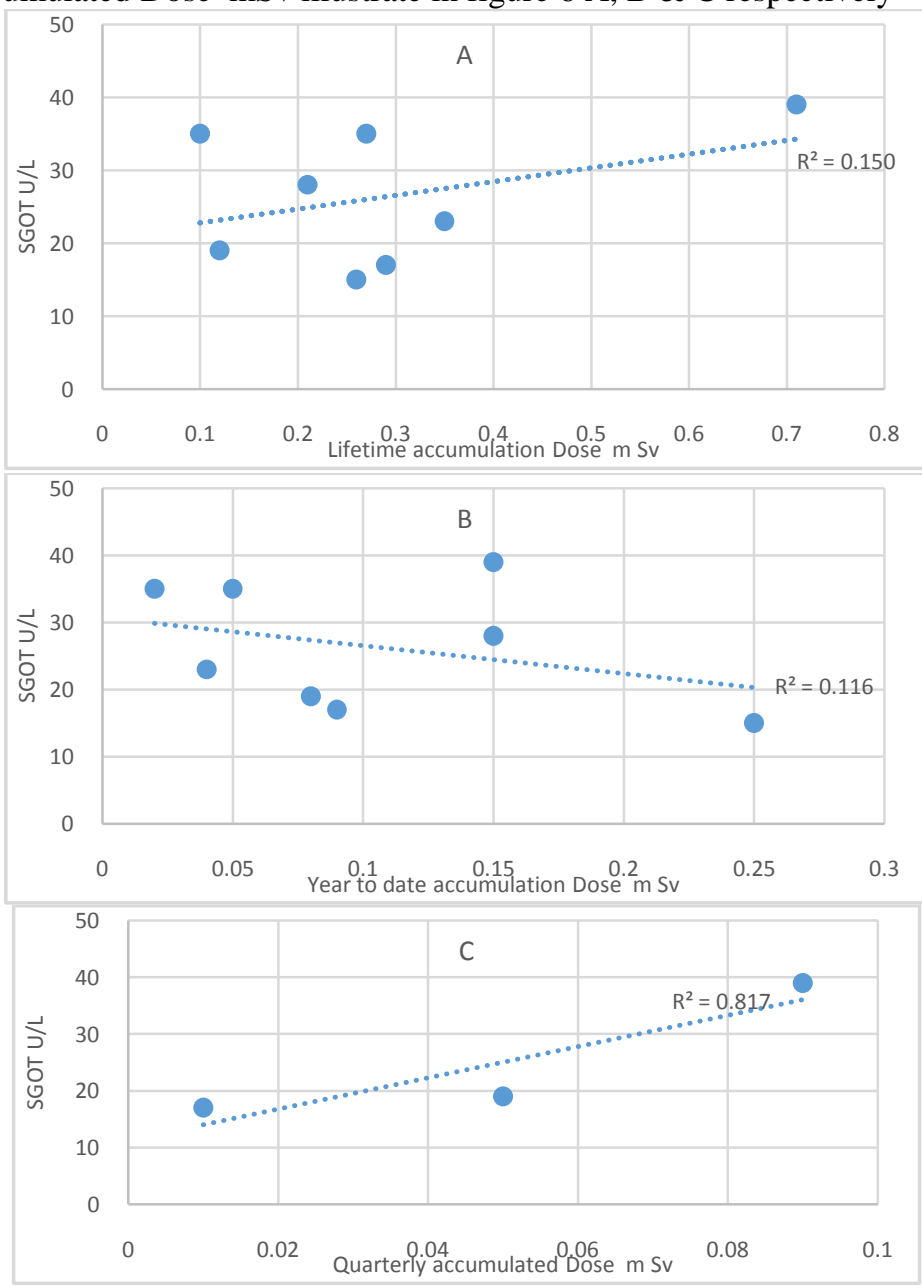

Figure 6 - correlation between SGOT U/Lwith Lifetime accumulation Dose mSv, Year to date accumulation Dose $\mathrm{mSv}$ and Quarterly accumulated Dose mSv A, B \& C respectively 
The correlation between SGPTU/Lwith Lifetime accumulation Dose mSv, Year to date accumulation Dose $\mathrm{mSv}$ and Quarterly accumulated Dose $\mathrm{mSv}$ illustrate in figure $7 \mathrm{~A}, \mathrm{~B} \& \mathrm{C}$ respectively.
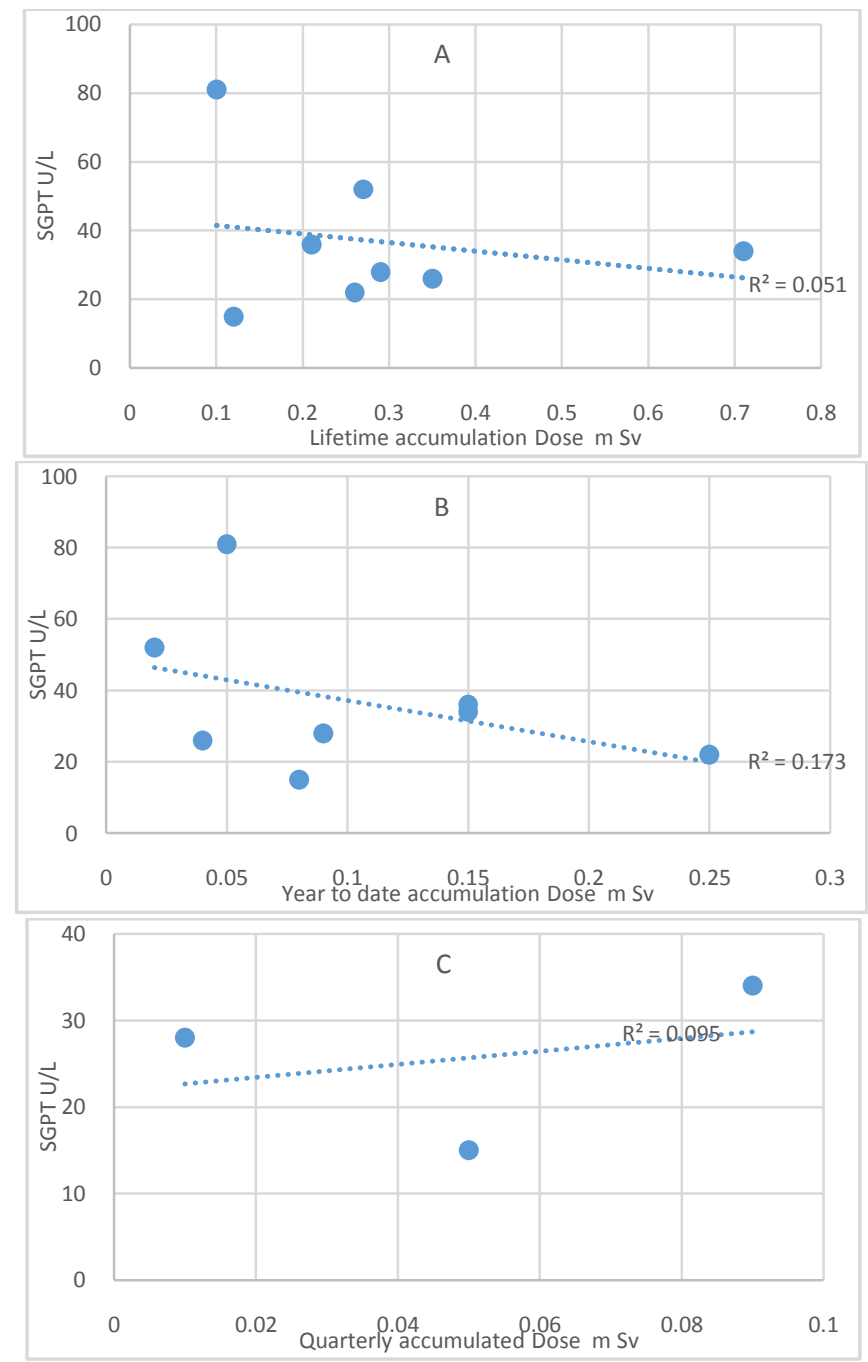

Figure 7 - correlation between SGPT U/Lwith Lifetime accumulation Dose mSv, Year to date accumulation Dose $\mathrm{mSv}$ and Quarterly accumulated Dose $\mathrm{mSv}$ A, B \& C respectively

\section{Discussion}

Blood cell is a well document effect for ionizing radiation and contribute to the hematopoietic syndrome, observed in mammals following by whole body irradiation (Billings et al., 2014).Immediate life threatening effects unaccompanied with low dose $(<1 \mathrm{~Sv})$ but long-term effects may be real and should be given serious consideration (Tucker, 2008). White blood cells are the most sensitive to gamma in the long- term effect (Sanzari et al., 2013).Reduction in blood cell counts in a dose-dependent manner but WBCs are less dependent (Maks et al., 2011)

In the current study, we found strong liner correlation between peripheral blood count and liver enzyme with quarter accumulationdose, knowing that we ignore the results of all employees who have received a small radiation dose $(<0.1 \mathrm{mSv})$ in the last three months.the correlation is strong positive for $\mathrm{RBCs}(\mathrm{R}=0.9)$, WBCs $(\mathrm{R}=0.995)$ and SGOT liver enzyme $(\mathrm{R}=0.934)$ but moderate negative for platelets count $(\mathrm{R}=-0.569)$ and positive for SGPT liver enzyme (0.309).

The correlation between peripheral blood count and liver enzyme with Lifetime and Year to date accumulation dose ranging from mild to moderate correlation (R $0.05-0.6)$. We suppose this correlation are not clear in Lifetime and Year to date accumulation dose because lifespan of RBCs 120 day (Clark1988),

Mean lifespan of RBC is 115 days; this value may vary between 70 and 140 days(Mock et al 2011),The typical life span of a platelet is about 10 days and Lifespan for WBCs about 21 day. (Dee et al 2010). For this reasons long term effect of low dose resulted from Lifetime and Year to date accumulation dose is not clear in correlation so when we ignored this doses we obtained on strong correlation between peripheral blood count with quarter accumulation dose except platelets count because have very short lifespan. 


\section{References}

[1] Billings, P. C., Romero-Weaver, A. L., \& Kennedy, A. R. (2014). Effect of gender on the radiation sensitivity of murine blood cells. Gravitational and Space Research, 2(1), $25 \mathrm{e} 31$.

[2] Dee UnglaubSilverthorn, Bruce R. Johnson, William C. Ober, Claire W. Garrison and Andrew C. Silverthorn. (2010) Hyman physiology anintegrated approach 5 th ed, ch 16 p 546-567

[3] Fliedner, T. M., Graessle, D. H., Meineke, V., \&Feinendegen, L. E. (2012). Hemopoietic response to low dose-rates of ionizing radiation shows stem cell tolerance and adaptation. Dose Response, 10(4), 644-663.

[4] Hall, E. J., \&Giaccia, A. (2008). Radiobiology for the radiologist (6th ed.). Philadelphia, PA: Lippincott, Williams \& Wilkins.

[5] Holl, V., Coelho, D., Weltin, D., Dufour, P., Gueulette, J., \&Bischoff, P. (2000). Ex vivo determination of the effect of whole-body exposure to fast neutrons on murine spleen cell viability and apoptosis. Radiation Research, 154(3), 301-306.

[6] Kutkov, V., Buglova, F., \& McKenna, T. (2011). Severe deterministic effects of external exposure and intake of radioactive material: basis for emergency response criteria. Journal of Radiological Protection, 31(2), 237-253.

[7] Maks, C. J., Wan, X. S., Ware, J. H., Romero-Weaver, A. L., Sanzari, J. K., Wilson, J. M., et al. (2011). Analysis of white blood cell counts in mice after gamma- or proton-radiation exposure. Radiation Research, 176(2), 170-176.

[8] Mock DM, Matthews NI, Zhu S, Strauss RG, Schmidt RL, Nalbant D, Cress GA, Widness JA. (2011). Red blood cell (RBC) survival determined in humans using RBCs labeled at multiple biotin densities. Transfusion.51,1047-1057.

[9] Sanzari, J. K., Wan, X. S., Krigsfeld, G. S., Wroe, A. J., Gridley, D. S., \& Kennedy, A. R. (2013). The effects of gamma and proton radiation exposure on hematopoietic cell counts in the ferret model. Gravitational and Space Research, 1(1), 79-94.

[10] Tucker, J. D. (2008). Low-dose ionizing radiation and chromosome translocations: a review of the major consideration for human biological dosimetry. Mutation Research, 659(3), 211-220.

[11] Ware, J. H., Sanzari, J., Avery, S., Sayers, C., Krigsfeld, G., Nuth, M., et al. (2010). Effects of proton radiation dose, dose rate and dose fractionation on hematopoietic cells in mice. Radiation Research, 174(3), 325-330.

[12] Werner Ru“hm1 • Gayle E. Woloschak2 • Roy E. Shore3, et al. (2015) Dose and dose-rate effects of ionizing radiation: a discussion in the light of radiological protection" Radiat Environ Biophys online. 